\title{
Parasitic infections in pond-reared rainbow trout Oncorhynchus mykiss in Denmark
}

\author{
K. Buchmann ${ }^{1, *}$, J. Bresciani ${ }^{2}$ \\ ${ }^{1}$ Department of Veterinary Microbiology, Section of Fish Diseases, ${ }^{2}$ Department of Ecology and Molecular Biology, \\ Section of Zoology, Royal Veterinary and Agricultural University, 13 Bülowsvej, DK-1870 Frederiksberg C, Denmark
}

\begin{abstract}
From October 1993 to December 1995, 5 Danish freshwater rainbow trout Oncorhynchus mykiss farms were surveyed for parasites; the most comprehensive survey to date in Denmark. A total of 805 fish, aged $0+$ and $1+$, were examined, and the parasites were identified by light microscopy, scanning electron microscopy and histochemistry. Prevalence (protozoans and metazoans; and abundance (metazoans) were recorded. The 12 protozoans found were: an intestinal diplomonadid flagellate, the ectoparasitic kinetoplastid Ichthyobodo necator, and the ciliates Ichthyophthirius multifiliis Chilodonella piscicola, Capriniana (Trichophrya) sp., Trichodina nigra, T. mutabilis, T fultoni, Trichodinella epizootica, Apiosoma sp., Ambiphrya sp. and Epistylis sp. The 10 metazoan species found were the myxosporean organism PKX, the monogeneans Gyrodactylus derjavini and G. salaris, the digeneans Diplostomum spathaceum and Tylodelphys clavata, the cestodes Proteocephalus exiguus. $P$. longicollis, Eubothrium crassum, and Triaenophorus nodulosus, and the crustacean Argulus foliaceus. The diplomonad occurred predominantly in anorectic undersized fish, and was associated with mortality. I. necator produced discoloration and epidermal hyperplasia and $I$. multifiliis infections were associated with mortalities. G. salaris and $G$. derjavini produced alterations (lesions and hyperplasia) of the host epidermis visible in the scanning electron microscope. Some D. spathaceum infections caused cataract. Prevalence of $I$. multifiliis increased with temperature (maximum at 16 to $20^{\circ} \mathrm{C}$ ), whereas the diplomonad had highest prevalence at 1 to $5^{\circ} \mathrm{C}$. Likewise, the gyrodactylids occurred more abundantly at lower temperatures
\end{abstract}

KEY WORDS: Rainbow trout - Oncorhynchus mykiss Parasites - Protozoa Metazoa Fish farming Aquaculture Epidemiology

\section{INTRODUCTION}

Farming of rainbow trout Oncorhynchus mykiss in freshwater has a century-long history in Denmark and during this time production has increased significantly. Thus, at present a total of 486 Danish freshwater farms produce 35000 metric tonnes of this fish annually. Worldwide, rainbow trout is host for more than 23 protozoans (Lom \& Dykova 1992) and at least 169 metazoan parasites (Buchmann et al. 1995a). Thus, this often translocated fish native to Canada can be infected both by specific heartland parasites and by those with lower host specificity (Kennedy \& Bush 1994). Knowledge of the parasite fauna in cul-

•E-mail:kurt.buchmann@vetmi.kvl.dk tured salmonids has been achieved through more than a dozen studies (Table 1). However, there are only a few surveys over extended time periods covering several taxonomic parasite groups: Wootten \& Smith (1980) in Scotland, Rosengarten (1985) in Germany, and Poynton \& Bennett (1985) in the UK. A preliminary 1 yr study on parasites in Danish trout production was presented by Buchmann et al. (1995b). This work has now been expanded and the present paper presents the results from a 27 mo survey of parasites in rainbow trout from 5 Danish farms, and aims to disclose factors influencing the parasite occurrence. This will provide a basis for implementation of procedures against productionlimiting effects of parasites in the farms, and will facilitate evaluation of possible interactions with wild fish stocks 
Table 1 Previous investigations on parasitic infections in farmed salmonids

\begin{tabular}{|c|c|c|c|c|c|}
\hline Author & $\begin{array}{l}\text { Geographical } \\
\text { region }\end{array}$ & Host & $\begin{array}{l}\text { No of fish } \\
\text { examined }\end{array}$ & Period & Parasites recorded \\
\hline $\begin{array}{l}\text { Zitnan \& Cankovic } \\
(1970)\end{array}$ & Bosnia-Herzegovina & Oncorhynchus mykiss & $\begin{array}{c}\text { No } \\
\text { information }\end{array}$ & $1966-1968$ & $\begin{array}{l}\text { Protozoa and } \\
\text { metazoa }\end{array}$ \\
\hline Wootten (1972) & England & O. mykiss & 125 & Jan-Dec 1968 & Eubothrium crassum \\
\hline $\begin{array}{l}\text { Hare \& Frantsi } \\
\text { (1974) }\end{array}$ & Canada & $\begin{array}{l}\text { Salmo salar } \\
\text { Salvelinus fontinalis } \\
\text { O. mykiss }\end{array}$ & $\begin{array}{r}317 \\
207 \\
34\end{array}$ & May-July 1972 & $\begin{array}{l}\text { Protozoa } \\
\text { Metazoa }\end{array}$ \\
\hline Robertson (1979) & Scotland & $\begin{array}{l}\text { S. salar } \\
\text { O. mykiss }\end{array}$ & $\begin{array}{l}>420 \\
>195\end{array}$ & May-Dec 1978 & Ichthyobodo necator \\
\hline $\begin{array}{l}\text { Wootten \& Smith } \\
(1980)\end{array}$ & Scotland & S. salar & 625 & $\begin{array}{l}\text { May } 1973- \\
\text { Apr } 1975\end{array}$ & $\begin{array}{l}\text { Protozoa } \\
\text { Metazoa }\end{array}$ \\
\hline $\begin{array}{l}\text { McGuigan \& } \\
\text { Sommerville (1985) }\end{array}$ & Scotland & O. mykiss & 40 & $\begin{array}{l}\text { Summer and } \\
\text { autumn } 1980\end{array}$ & $\begin{array}{l}\text { Protozoa } \\
\text { Metazoa }\end{array}$ \\
\hline $\begin{array}{l}\text { Poynton \& Bennett } \\
\text { (1985) }\end{array}$ & England & $\begin{array}{l}\text { O. mykiss } \\
\text { S. trutta }\end{array}$ & $\begin{array}{r}252 \\
68\end{array}$ & $\begin{array}{l}\text { Dec } 1980- \\
\text { Nov } 1981\end{array}$ & $\begin{array}{l}\text { Protozoa } \\
\text { Metazoa }\end{array}$ \\
\hline Rosengarten (1985) & Germany & O. mykiss & 1012 & $\begin{array}{l}\text { Sept } 1983- \\
\text { May } 1985\end{array}$ & $\begin{array}{l}\text { Protozoa } \\
\text { Metazoa }\end{array}$ \\
\hline Poynton (1986) & England & $\begin{array}{l}\text { O. mykiss } \\
\text { S. trutta }\end{array}$ & $\begin{array}{l}877 \\
191\end{array}$ & $\begin{array}{l}\text { Dec } 1980- \\
\text { Feb } 1983\end{array}$ & $\begin{array}{l}\text { Hexamita salmonis } \\
\text { Loma salmonae }\end{array}$ \\
\hline $\begin{array}{l}\text { Stables \& Chappell } \\
(1986 b)\end{array}$ & Scotland & O. mykiss & $>960$ & $\begin{array}{l}\text { Jan } 1982- \\
\text { Aug } 1984\end{array}$ & Diplostomum spp. \\
\hline $\begin{array}{l}\text { Cone \& Cusack } \\
\text { (1988) }\end{array}$ & Canada & $\begin{array}{l}\text { S. fontinalis } \\
\text { S. salar } \\
\text { O. mykiss }\end{array}$ & $>1000$ & $\begin{array}{l}\text { Jan 1984- } \\
\text { Mar } 1987\end{array}$ & $\begin{array}{l}\text { Gyrodactylus salmonis } \\
\text { G. colemanensis }\end{array}$ \\
\hline Field \& Irwin (1994) & Northern Ireland & O. mykiss & $>1800$ & $1990-1992$ & Diplostomum spp. \\
\hline $\begin{array}{l}\text { Buchmann et al. } \\
\text { (1995b) }\end{array}$ & Denmark & O. mykiss & 447 & $\begin{array}{l}\text { Oct } 1993- \\
\text { Nov } 1994\end{array}$ & $\begin{array}{l}\text { Protozoa } \\
\text { Metazoa }\end{array}$ \\
\hline
\end{tabular}

\section{MATERIALS AND METHODS}

Trout farms. The 5 freshwater trout farms raising market size fish were all located in the western part of Denmark (Jutland) (Table 2). The annual variation of temperature in the inlet water to the farms is presented in Fig. 1.

Antiparasitic treatments. The farmers used copper sulphate, chloramine and formaldehyde prophylacti- cally against ectoparasitic infections throughout the year. Dimetridazole (Emtryl) was applied for treatment of hexamitiasis (used in feed or in water bath) until September 1995, when the drug was banned and withdrawn.

Sampling protocol. The farms were examined over 27 mo from October 1993 to December 1995. Monthly samples usually comprised 5 to 15 fish per farm. Fish less than 2 yr old were selected randomly (frequent

Table 2. Specifications of the 5 trout farms

\begin{tabular}{|c|c|c|c|c|c|c|c|c|c|}
\hline \multirow[t]{2}{*}{ Farm } & \multirow{2}{*}{$\begin{array}{c}\text { Annual } \\
\text { production }(t)\end{array}$} & \multirow[t]{2}{*}{ Type of fish } & \multirow[t]{2}{*}{ Water source } & \multirow{2}{*}{$\begin{array}{l}\text { Connection to } \\
\text { other farms }\end{array}$} & \multirow{2}{*}{$\begin{array}{c}\text { Temperature } \\
\text { range }\left({ }^{\circ} \mathrm{C}\right)\end{array}$} & \multicolumn{4}{|c|}{ Chemicals used $^{2}$} \\
\hline & & & & & & $\mathrm{Ch}$ & $\mathrm{Co}$ & Di & Fo \\
\hline 1 & 50 & $\begin{array}{l}\text { Fry, fingerlings, } \\
\text { market size }\end{array}$ & $\begin{array}{l}\text { Stream } \\
\text { Well }\end{array}$ & Isolated & $1-16$ & & + & + & + \\
\hline 2 & 98 & $\begin{array}{l}\text { Fry, fingerlings, } \\
\text { market size }\end{array}$ & $\begin{array}{l}\text { Stream } \\
\text { Well }\end{array}$ & Isolated & $2-16$ & + & & + & + \\
\hline 3 & 150 & $\begin{array}{l}\text { Fry, fingerlings, } \\
\text { market size }\end{array}$ & Stream & Several & $0-20$ & + & + & + & + \\
\hline 4 & 90 & $\begin{array}{l}\text { Fingerlings, } \\
\text { market size }\end{array}$ & Natural lake & Several & $2-23$ & & + & & + \\
\hline 5 & 275 & $\begin{array}{l}\text { Fingerlings, } \\
\text { market size }\end{array}$ & Stream & Several & $1-20$ & & + & & + \\
\hline
\end{tabular}




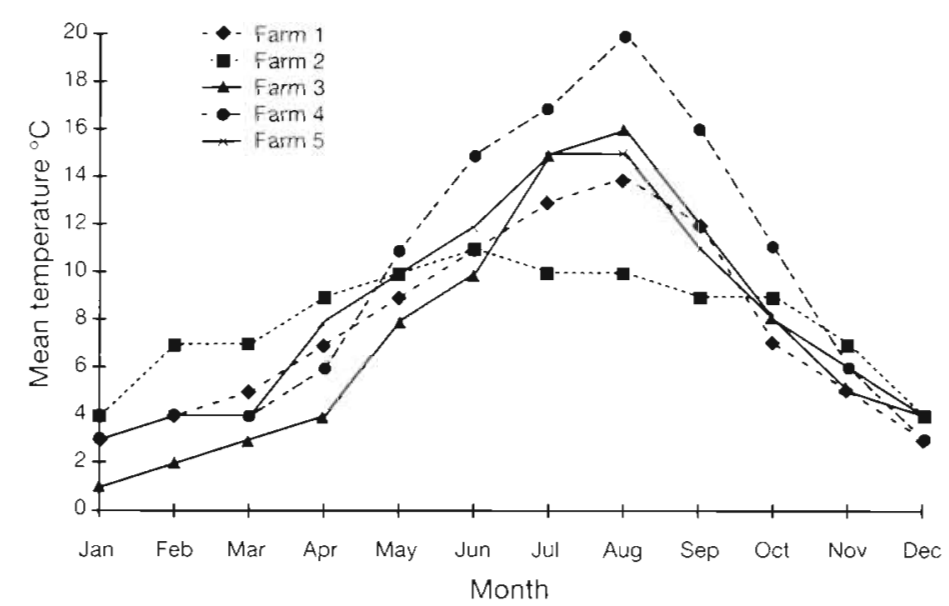

Fig. 1. Mean monthly temperatures of inlet water to the 5 trout farms $4^{\circ} \mathrm{C}$, dehydrated through a series of graded acetone, mounted, critical-point dried, sputtered with gold and studied in a JEOL scanning electron microscope. TEM for proper identification of the diplomonads was not conducted. Imprints of kidneys were tested for PKX organisms using the modified lectin (Griffonia simplicifolia) binding technique (Hedrick et al. 1992) as described by Buchmann et al. (1995b). Cestodes and digeneans were fixed in $70 \%$ ethanol or $4 \%$ phosphate buffered formaldehyde and mounted in glycerine gelatine. Ammonium picrate/glycerine was used as mounting medium for gyrodactylids (Malmberg 1957). size grading had mixed the $0+$ and $1+$ cohorts). Total body lengths $(\mathrm{cm})$ were registered. A total of 805 fish were examined. The number of fish examined per farm ranged from 132 to 192 , and per month it ranged from 57 to 84 (27 mo combined) (Table 3). The majority of fish examined were smaller than $16 \mathrm{~cm}$ and were collected at temperatures below $16^{\circ} \mathrm{C}$ (Figs. $2 \& 3$ ). The relative proportions of size groups in different temperature intervals are shown in Fig. 4

Examination of fish. Fish were either placed in small tanks in farm water until examination within $2 \mathrm{~h}$, or taken in cooled plastic bags $\left(1\right.$ to $\left.10^{\circ} \mathrm{C}\right)$ to the laboratory, where they were examined within $24 \mathrm{~h}$.

The fins, gills, skin, eyes (lens and corpus vitreum), body cavity, heart. liver, spleen, kidney, swim bladder, oesophagus, stomach, pyloric caeca and intestine were examined using first a dissecting microscope (10 to $40 \times$ magnification) and subsequently a compound microscope (100 to $1000 \times$ magnification). Identification of trichodinids was conducted using skin or gill mucus smears incubated with $2 \%$ silver nitrate (20 $\mathrm{min})$ and subsequent UV exposure (10 to $20 \mathrm{~min}$ ) (Lom \& Dykova 1992, modified). Selected ectoparasites on gills and fins were fixed in $2.5 \%$ glutaraldehyde in $0.1 \mathrm{M}$ cacodylate buffer ( $\mathrm{pH} 7.4$ ) for at least $48 \mathrm{~h}$, postfixed in $1 \%$ osmium tetroxide for $1 \mathrm{~h}$ at

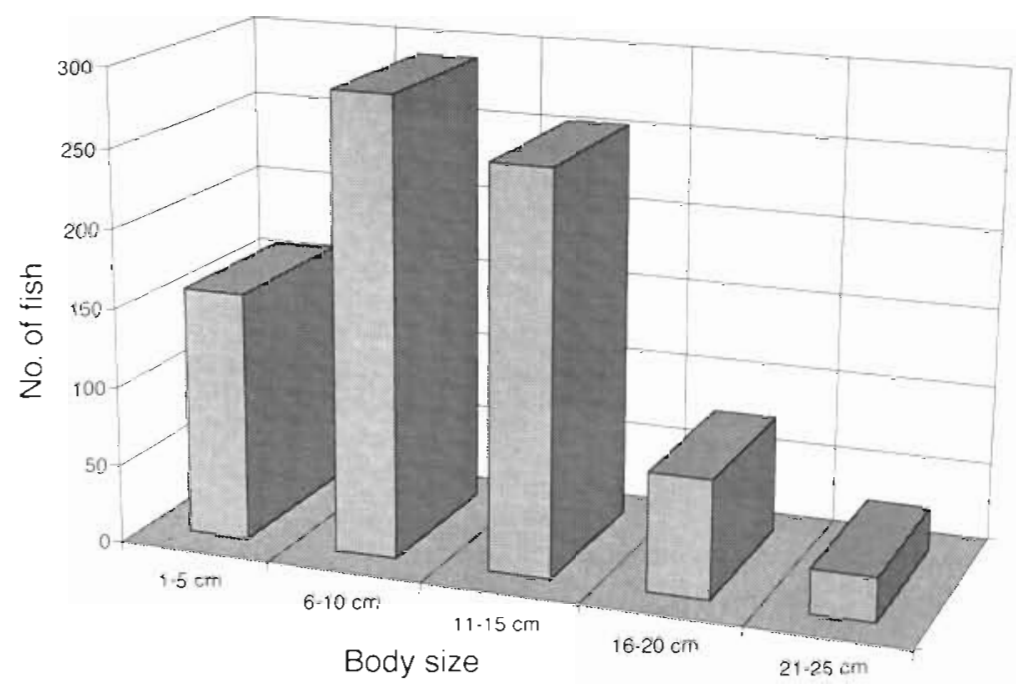

Fig. 2. Oncorhynchus mykiss. Distribution of examined fish according to size group

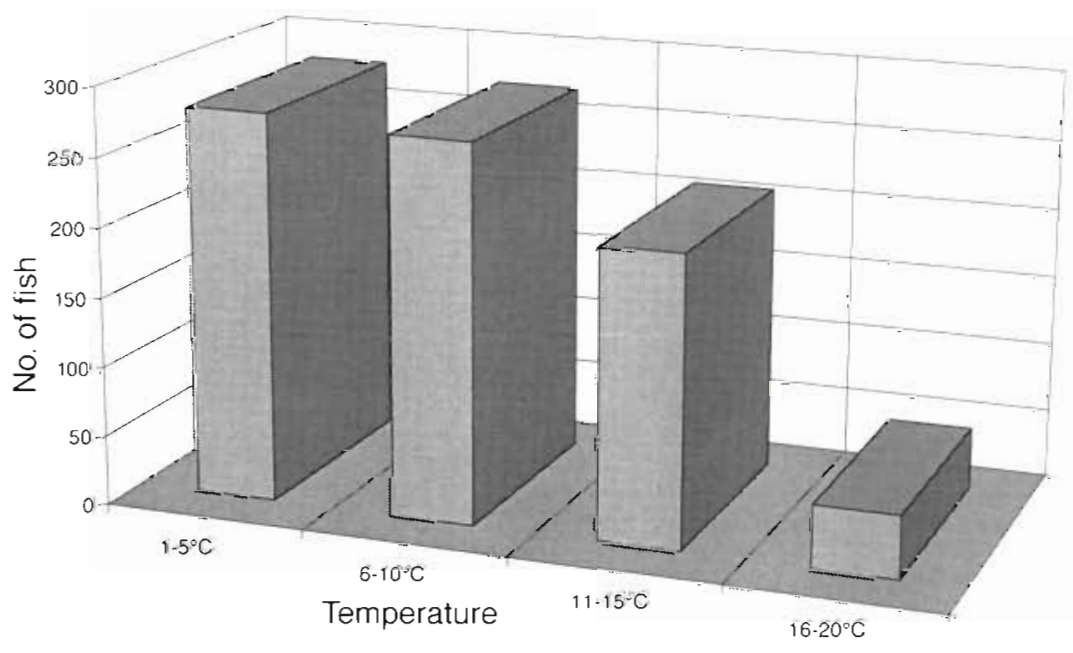

Fig. 3. Oncorhynchus mykiss. Distribution of examined fish according to the temperature at the farm from which they were sampled 
Table 3. Oncorhynchus mykiss. Number of trout from the 5 farms examined in 12 mo (data from 1993 to 1995 combined)

\begin{tabular}{|c|c|c|c|c|c|c|c|c|c|c|c|c|c|}
\hline & $\operatorname{Jan}$ & Feb & Mar & Apr & May & Jun & Jul & Aug & Sep & Oct & Nov & Dec & Total \\
\hline Farm 1 & 19 & 18 & 20 & 17 & 16 & 12 & 10 & 18 & 12 & 5 & 24 & 16 & 187 \\
\hline Farm 2 & 5 & 10 & 1.5 & 15 & 16 & 15 & 14 & 11 & 11 & 7 & 10 & 12 & 141 \\
\hline Farm 3 & 5 & 10 & 16 & 0 & 10 & 1.5 & 10 & 11 & 12 & 7 & 14 & 22 & 132 \\
\hline Farm 4 & 18 & 18 & 14 & 14 & 16 & 15 & 11 & 12 & 12 & 30 & 21 & 11 & 192 \\
\hline Farm 5 & 15 & 6 & 19 & 18 & 10 & 17 & 12 & 10 & 15 & 8 & 13 & 10 & 153 \\
\hline Total & 62 & 62 & 84 & 64 & 68 & 74 & 57 & 62 & 62 & 57 & 82 & 71 & 805 \\
\hline
\end{tabular}

Presentation of data. Terms used to designate parasites in the host population were prevalence (percentage of fish infected) and abundance (number of parasites per host including both infected and uninfected) as defined by Margolis et al. (1982). Data from consecutive years were pooled and presented on a monthly basis. Infection with the very mobile ectoparasites is expressed as present or not present (ectoparasitic flagellates and trichodinids) or abundance (gyrodactylids) (all monogeneans from individual fishes were collected and registered).

Statistics. The chi-square test was conducted to detect differences $(p<0.05)$ in month, size group or temperature.

\section{RESULTS}

\section{Overview}

The survey revealed a total of 12 protozoan and 10 metazaan parasite species for which selected SEM micrographs are shown in Fig. 5. A number of the par-

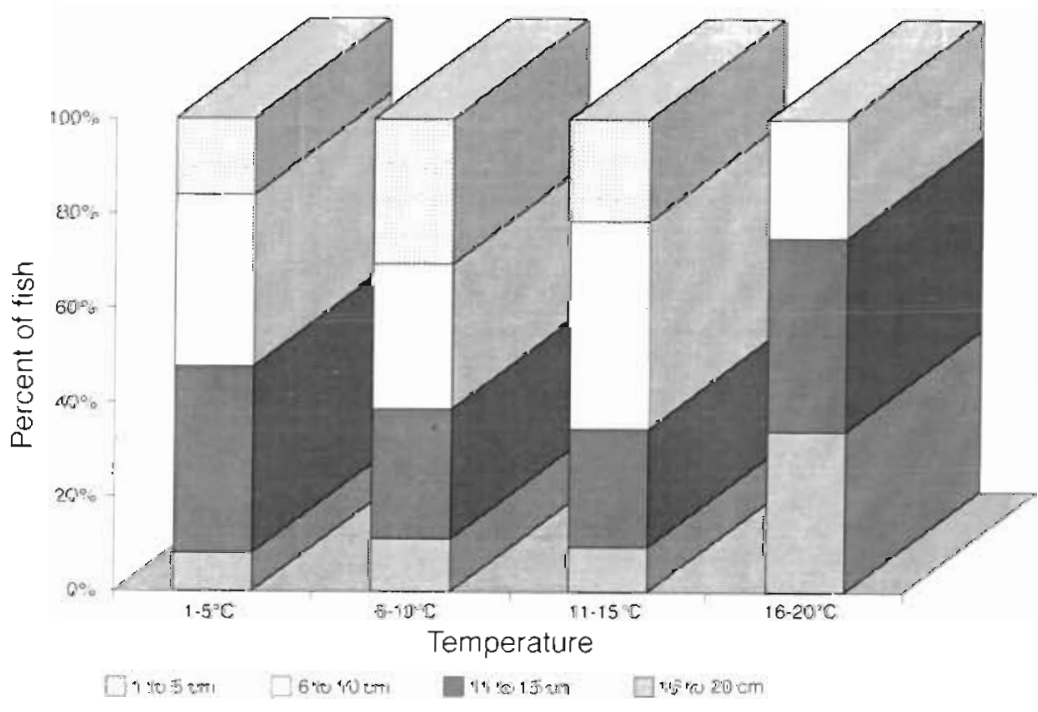

Fig. 4. Oncorhynchus mykiss. Relative proportions of size groups at the different temperature intervals asites occurred in all farms but some were restricted to one or few of the production plants. Thus, eye flukes and cestodes occurred predominantly in Farm 4 and the diversity varied considerably with Farm 4 as the most diverse whereas Farm 2 showed low diversity. Most of the prevalent parasites were detected in all seasons (Table 4) but the low prevalence of most parasites precluded statistical analysis of changes with season, temperature and size. The exception to this were Ichthyophthirius multifilis, the diplomonad, the eye flukes and the gyrodactylids.

\section{Protozoa}

Flagellates. The diplomonadid intestinal flagellate was found in all trout farms (although rare in Farm 4) but showed a predilection for smaller fish (Fig. 6a). Flagellate occurrence was connected with lethargy, anorexia and occasionally presence of yellowish mucus in the intestine. In one case (December 1.994, Farm 1) some fish mortality $(10 \%)$ was associated with heavy infections. The parasite occurred in all months (Table 4) but was less frequently detected at temperatures above $10^{\circ} \mathrm{C}$ (Fig. 6b). This indication of psychrophilia was not biased by examination of a greater number of large fish at higher temperatures. Relatively more small fish ( 1 to $5 \mathrm{~cm}$ ) were examined at temperatures from 11 to $15^{\circ} \mathrm{C}$ than at 1 to $5^{\circ} \mathrm{C}$ (Fig. 4). A less frequent occurrence at Farm 1 in January, February and March 1995 was associated with dimetridazole (Emtryl) water bath treatments.

The kinetoplastid ectoparasitic flagellate Ichthyobodo necator was found on fish skin and gills, most frequently in the first 4 mo of the year and less commonly from June (Table 4). In heavy infections this ectoparasite produced discoloration of the skin due to hyperplasia and excessive blue-grey mucus production. 


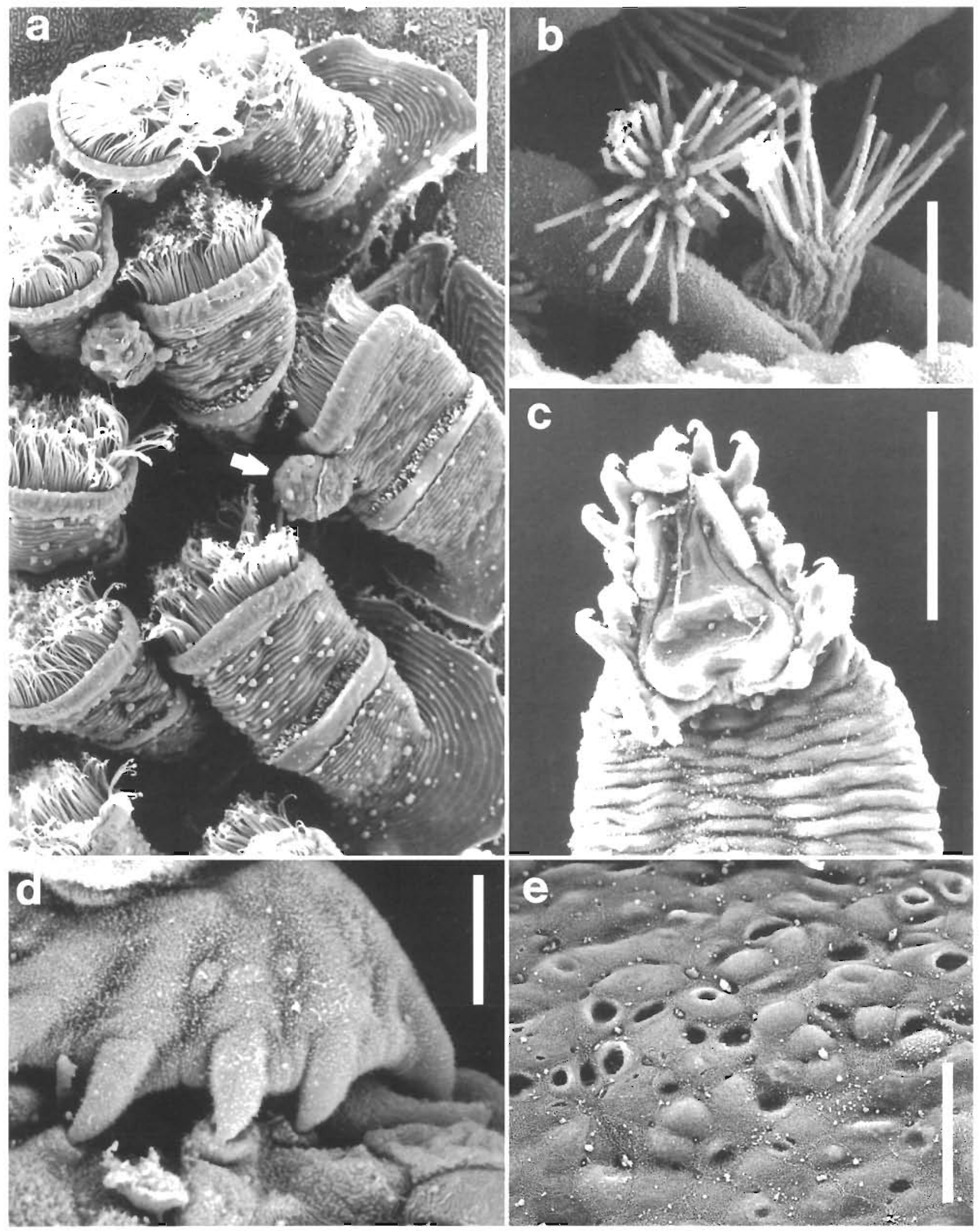

Fig. 5. Scanning electron micrographs (SEM) of selected parasites from Danish farmed rainbow trout Oncorhynchus mykiss (a) Ambiphrya sp. on fin; note microconjugant (arrow). Scale bar $=20 \mu \mathrm{m}$. (b) Capriniana (Trichophrya) sp. on gill filament. Scale bar $=20 \mu \mathrm{m}$. (c) Gyrodactylus derjavini, ventral view, showing opisthaptor with 16 marginal hooklets (stout and short form) and sheath with 2 hamuli and ventral bar. Scale bar $=50 \mu \mathrm{m}$. (d) Opisthaptor of $G$. derjavini showing insertion of marginal hooklets into the pectoral fin epithelium. Scale bar $=10 \mu \mathrm{m}$. (e) Effects of $G$. derjavini opisthaptor on the epithelium. Note perforations 
Table 4. Oncorhynchus mykiss. Parasites recorded at 5 trout farms (1993 to 1995 combined). Months are numbered I to XII (Jan to Dec)

\begin{tabular}{|c|c|c|c|c|c|c|c|c|c|c|c|c|c|c|c|c|c|c|}
\hline \multirow[t]{2}{*}{ Parasite species } & \multirow[t]{2}{*}{ Location in host } & \multicolumn{5}{|c|}{ Recorded at Farm } & \multicolumn{12}{|c|}{ Month of record } \\
\hline & & 1 & 2 & 3 & 4 & 5 & 1 & II & III & IV & V & V1 & VII & VIII & IX & $x$ & XI & XII \\
\hline \multicolumn{19}{|l|}{ Protozoa } \\
\hline \multicolumn{19}{|l|}{ Mastigophora } \\
\hline Diplomonadid & Pyloric caeca, intestine & + & + & + & + & + & + & + & + & + & + & + & + & + & + & + & + & + \\
\hline Ichthyobodo necator & Fins, skin, gills & + & & + & + & + & + & + & + & + & & & + & & + & + & & + \\
\hline \multicolumn{19}{|l|}{ Ciliophora } \\
\hline Ichthyophthirius multifiliss & Fins, skin, gills & + & & + & + & + & & & & & & & + & + & t & + & + & \\
\hline Chilodonella piscicola & Skin & & & & & + & & & & & + & & & & & & & \\
\hline Capriniana sp. & Gills & + & & & + & & & & & & & & + & & & & + & \\
\hline Trichodina nigra & Skin, fins, gills & + & t & + & + & + & + & + & + & + & & & + & + & + & & + & + \\
\hline T. mutabilis & Skin, fins, gills & + & + & + & + & + & + & + & + & + & & & + & + & + & & + & + \\
\hline T. fultoni & Skin, fins, gills & + & + & + & + & + & + & + & + & + & & & + & + & + & & + & + \\
\hline Trichodinella epizootica & Gills & + & & + & + & + & & + & & & & & + & & & & + & + \\
\hline Epistylis sp. & Skin, fins & + & + & + & + & + & + & + & + & + & + & & + & + & + & & + & + \\
\hline Ambiphrya sp. & Skin, fins & + & + & + & + & + & + & + & + & + & + & & + & + & + & & + & + \\
\hline Apiosoma sp. & Skin, fins & + & + & + & + & + & + & + & + & + & + & & + & + & + & & + & + \\
\hline \multicolumn{19}{|l|}{ Metazoa } \\
\hline \multicolumn{19}{|l|}{ Myxosporea } \\
\hline $\mathrm{PKX}^{6}$ & Kidney & + & + & + & + & + & & & & + & + & + & + & & + & & + & + \\
\hline \multicolumn{19}{|l|}{ Monogenea } \\
\hline Gyrodactylus salaris & Fins, skin & + & + & & + & + & + & & + & + & + & & & & & & + & + \\
\hline G. derjavini & Fins, skin & + & & + & + & + & + & + & + & + & + & + & + & + & + & + & + & + \\
\hline \multicolumn{19}{|c|}{ Digenea } \\
\hline Diplostomum spathaceumb & Eye lens & & & & + & + & + & + & + & + & + & + & + & + & + & + & + & + \\
\hline Tylodelphys clavatal" & Corpus vitreum & & & & + & & + & + & + & + & + & & + & + & + & + & + & + \\
\hline \multicolumn{19}{|l|}{ Cestoda } \\
\hline Eubothrium crassum ${ }^{b}$ & Pyloric caeca, intestine & & & & + & & + & + & + & & & & & & & + & & \\
\hline Proteocephalus sp.' & Intestine & & & & + & & + & & & & & & & & & + & & \\
\hline P. exiguus ${ }^{b}$ & Intestine & & & & + & & + & + & & & + & & & & & + & & \\
\hline P. longicollis ${ }^{\mathrm{b}}$ & Intestine & & & & + & & & & & & + & & & & & & & \\
\hline Triaenophorus nodulosus & Body cavity & & & & + & & & & + & & & & + & & & + & + & \\
\hline \multicolumn{19}{|c|}{ Crustacea } \\
\hline Argulus foliaceus & Skin & & & & + & & & & & & & & & + & & & & \\
\hline Total no. of taxa & & 14 & 9 & 11 & 22 & 15 & & & & & & & & & & & & \\
\hline
\end{tabular}

Ciliates. The ciliate Ichthyophthirius multifiliis, which infects skin, fins and gills, displayed a characteristic thermophilic infection pattern with no infections found between December and June but extreme infections (associated with 10 to $20 \%$ mortality in Farm 1 and 4 ponds) from July (the warmest month) to September with a decline in infection until November (Fig $7 \mathrm{a}, \mathrm{b}$ ). Pronounced hyperplasia of infected fin and gill epithelium was associated with the presence of trophonts in these tissues. Only a single case of Chilodonella piscicola infection was recorded (Table 4). The suctorian Capriniana (Trichophrya) sp. (Fig 5b) infected the gills of trout in 3 cases of which only one was severe (Farm 4, November 1995) (Table 4). However, no mortalities could be connected to the presence of this suctorian. The trichodinids included Trichodina nigra, $T$. mutabilis, $T$ fultoni (predominantly skin infection) and Trichodinella epizootica (exclusively gill infections). Micrographs of Trichodina species stained with silver nitrate were previously presented (Buchmann et al. 1995b). This genus was detected throughout the year whereas Trichodinella merely occurred sporadically (Table 4). Trichodinids were normally not associated with adverse conditions of fish. However, on one occasion, trout from Farm 2 which had been transferred to laboratory aquaria $\left(14^{\circ} \mathrm{C}\right)$ suffered heavy multiplication of Trichodina fultoni (data not shown). This caused anorexia and lethargy in the host fish suggesting an adverse effect of these parasites when occurring in large numbers. The sessile peritrich ciliates Apiosoma sp., Ambiphrya sp. (Fig. 5a) and Epistylis sp. were detected throughout the year (Table 4). No mortalities were evident in connection. with the presence of these ciliates. 

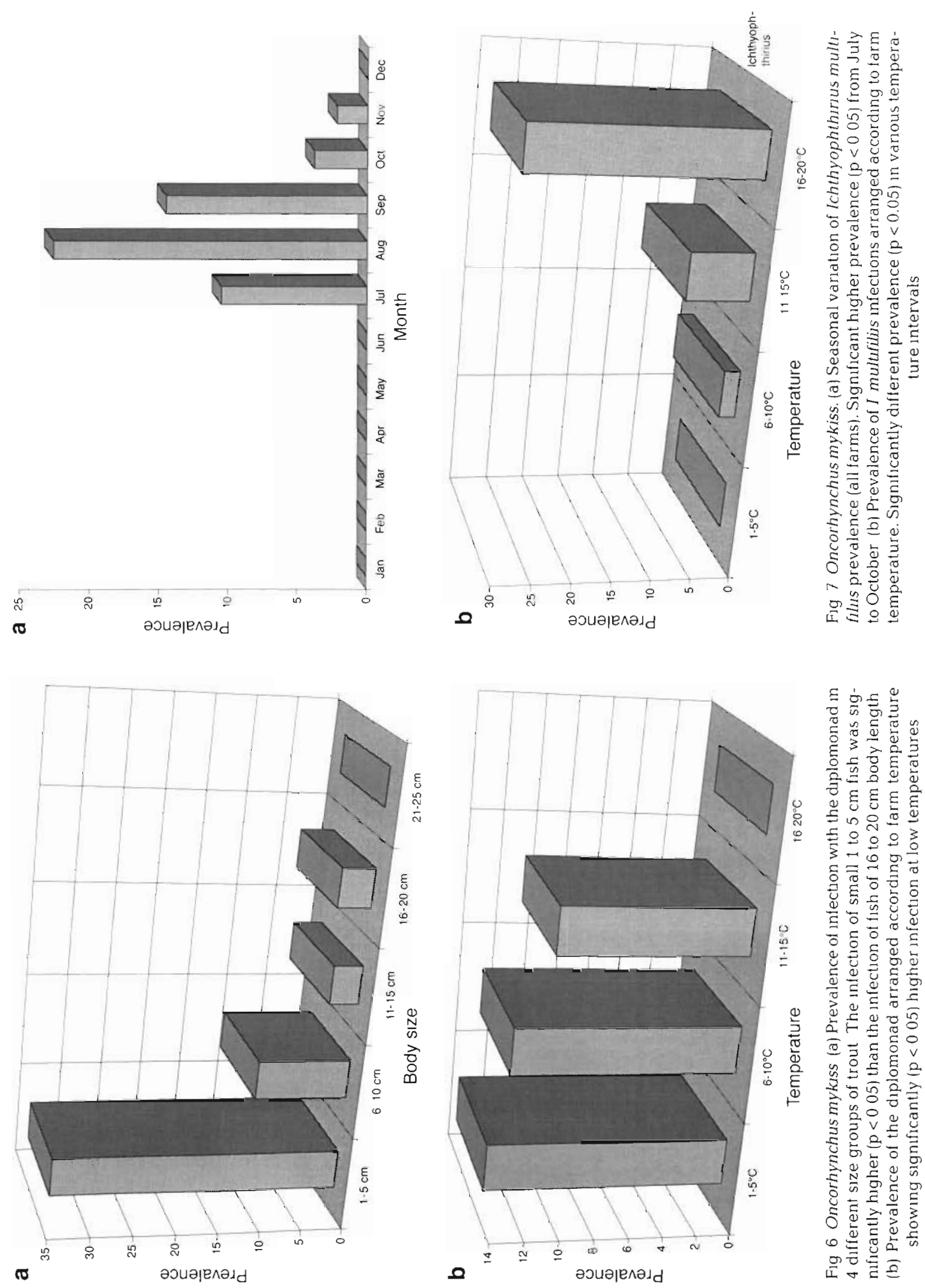

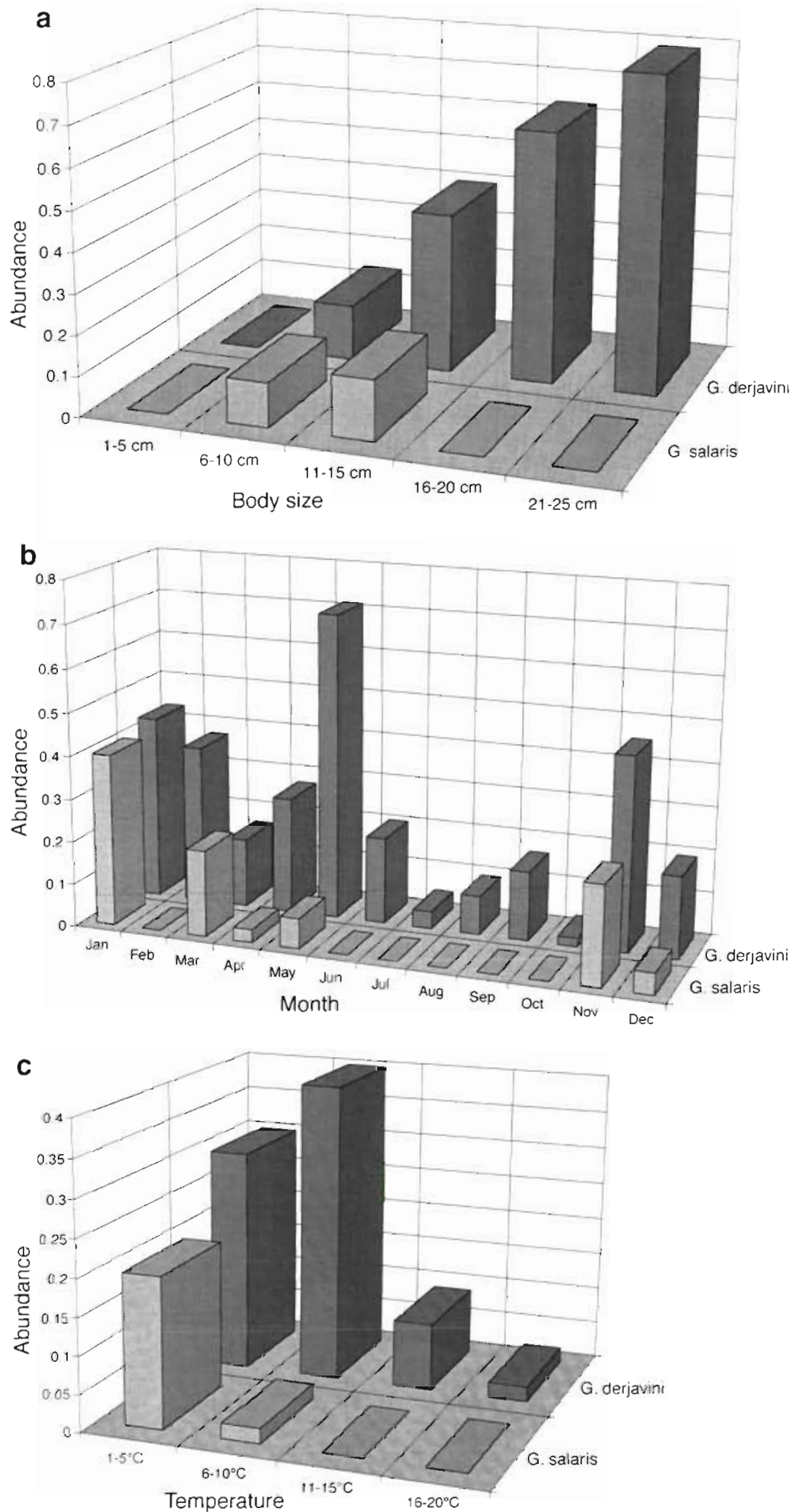

Fig. 8. Oncorhynchus mykiss. (a) Variation of Gyrodactylus spp. abundance in relation to the host size (body length). Larger fish $(11$ to $20 \mathrm{~cm}$ ) were significantly $(p<0.05)$ more infected than small fish (1 to $10 \mathrm{~cm})$. (b) Seasonal variation of Gyrodactylus spp. abundance showing significantly $(p<0.05)$ lower infection in July to October. (c) Occurrence of Gyrodactylus spp. arranged according to farm temperature at sampling time showing significant higher $(\mathrm{p}<0.05)$ infection at temperatures 1 to $10^{\circ} \mathrm{C}$ than at temperatures 11 to $20^{\circ} \mathrm{C}$

\section{Metazoans}

Myxosporeans. The myxosporean PKX was primarily registered from April until July although some positive samples were found in the autumn (Table 4). PKX was exclusively detected by using Griffonia simplicifolia lectin binding to kidney imprints. No gross pathological signs including kidney enlargement and focal lesions (Bucke et al. 1991, Hedrick et al. 1993) were seen even in the lectinpositive fish.

Monogeneans. Two species of the monogenean Gyrodactylus infected rainbow trout, $G$. salaris coexisted with $G$. derjavini at 2 farms ( 1 and 5). One farm (Farm 2) harboured no infection with monogeneans in fry, fingerlings or market size fish, but on 2 occasions (March and May, 1995) one specimen of $G$. salaris was recovered from the tail fin of a spawner. At Farm 3 only G. derjavini was found. Farm 4 was dominated by $G$. derjavini, but on 3 occasions (November, March and May) one specimen of $G$. salaris was recovered from the fins of fingerlings. An increase in abundance with decreasing temperature and increasing host size was seen (Fig. 8a-c). The penetration of $G$, derjavini marginal hooklets (Fig. 5c) into the fish epidermis produced changes visible (perforations of epithelia) in SEM studies of fin epithelium (Fig. 5d, e).

Digeneans. The 2 digenean trematode species Diplostomum spathaceum and Tylodelphys clavata were found at Farm 4 in all seasons (Table 4, Fig. 9a, b). With the exception of a few months D. spathaceum infected all the examined fish and a maximum of 43 parasites in one fish was recorded. Opacity of lenses in connection with the eye fluke infection was often observed. In contrast $T$. clavata was found irregularly in low prevalences and intensities (normally up to 11 parasites per fish, one case only with 22 parasites in one fish). At Farm 5 D. spathaceum was found in 2 cases only (January and April 1994 with prevalences of 10 and $20 \%$, respectively). These fish were imported from another farm during the winter. 

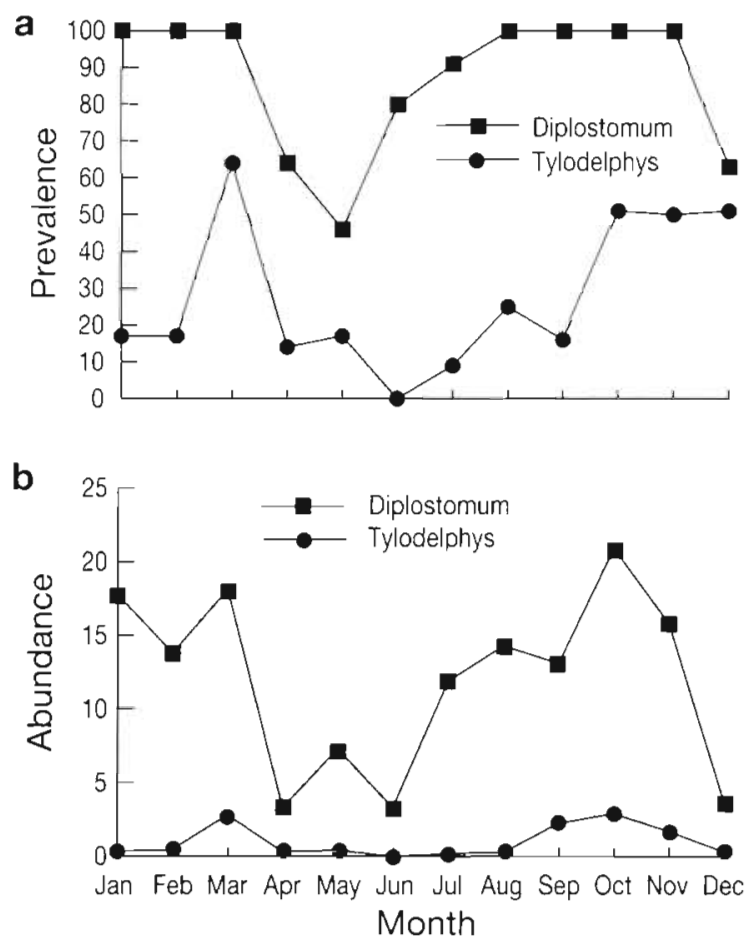

Fig. 9. Oncorhynchus mykiss. (a) Seasonal variation of prevalence at Farm 4 of 2 species of eye flukes. (b) Seasonal variation of abundance of 2 species of eye fluke at Farm 4 Diplostomum spathaceum but not Tylodelphus clavata abundance varied significantly $(p<0.05)$ during the year

Cestodes. Three species of cestodes infected fish at Farm 4 only. These included Eubothrium crassum, Proteocephalus exiguus (syn. $P$. neglectus, Hanzelova et al. 1995) and Triaenophorus nodulosus (Table 4). A specimen determined as Proteocephalus longicollis was recorded as well. Only one specimen of cestode was found in each fish. Copepods (putative intermediate hosts) were found as part of the intestinal content throughout the year.

Crustaceans. In one case only (August 1994) one specimen of Argulus foliaceus was recovered from a spawner at Farm 4.

\section{DISCUSSION}

A few investigations have previously been conducted on parasitic infections in Danish freshwater trout farms. Christensen et al. (1963) mentioned 4 protozoans and Diplostomum sp., Malmberg (1973) collected gyrodactylids, Christensen \& From (1978) mentioned anisakids, Hørlyck (1980) recorded Capriniana (Trichophrya) sp., From \& Hørlyck (1981) reported finding Proteocephalus percae (corrected to $P$. neglectus by Hanzelová \& Scholz 1992), Olesen (1985) recorded PKD and Buchmann et al. (1995b) mentioned 10 protozoans and 8 metazoans. The present paper adds Capriniana sp., Proteocephalus exiguus and $P$. longicollis to this list and gives a description of the occurrence in relation to hosts, season and temperature.

The total number of parasite taxa (12 protozoans and 10 metazoans) recorded in rainbow trout in this study is low compared to the more than 23 protozoan species listed by Lom \& Dykova (1992) and the 169 metazoan species recorded on a worldwide basis (Buchmann et al. 1995a). Especially metazoan species (with the exception of eye flukes) requiring intermediate hosts are relatively rare. The paucity of specific metazoans in rainbow trout introduced into countries far from the country of origin was treated by Kennedy \& Bush (1994). However even non-specialist parasites are rare in the trout ponds. This may be explained by the artificial conditions in the trout ponds, which exhibit an extreme sparcity of potential intermediate invertebrate hosts. In contrast, protozoans and monogeneans with direct life cycles are easily introduced and spread between host fishes. This corresponds to conditions found in similarly constructed salmon farms (Wootten \& Smith 1980). Frequent use of formaldehyde and copper sulphate could likewise explain the paucity of parasite species.

\section{Protozoans}

Flagellates. Infections with intestinal diplomonads were in a few cases associated with mortalities and morbidity in fry corresponding to previous observations on Hexamita salmonis (Moore 1923, Davis 1926, Uzman et al. 1965, Hare \& Frantsi 1974, Ferguson 1979). TEM studies on the Danish parasite should establish the exact taxonomic position of this flagellate. The infections in Danish farms were restricted to smaller anorectic fish (less than $10 \mathrm{~cm}$ total body length) and often associated with the presence of yellow mucus in the intestine (Uldal \& Buchmann 1996). Similarly coloured mucus was in some cases detected in $H$. salmonis infected trout by Poynton \& Bennett (1985). Larger fish and lightly infected fish mostly harbour the flagellates in the pyloric caeca and the anterior part of the intestine, whereas in heavily infected fry it has been detected throughout the entire length of the gut (Buchmann et al. 1995b, Uldal \& Buchmann 1996). Recent in vitro investigations (Buchmann \& Uldal 1996) have demonstrated that $H$. salmonis from rainbow trout preferentially reproduce at lower temperatures ( 5 to $10^{\circ} \mathrm{C}$ ), and temperatures of 15 and $20^{\circ} \mathrm{C}$ do not support significant in vitro growth of the organism. This is only partially reflected as a seasonal 
variation in the field studies due to the chemical treatment carried out in winter and the relatively low water temperatures at 2 farms during summer. However, when the diplomonad cases were analyzed in relation to water temperature a clearer picture of psychrophilia occurred. Poynton (1986) also presented evidence of more prevalent $H$. salmonis infections in the cold season.

Although the abundant occurrence of the kinetoplastid Ichthyobodo necator produced discolouration of the fish skin, few deleterious effects were apparent at the studied farms. Smaller fish seem to be more susceptible to gill infections (Robertson 1979) and, although larger fish are vulnerable to skin infections, hyperplasia of the skin and excessive mucus production (discolouration) seem to be the worst effects. This ectoparasitic kinetoplastid flagellate is commonly considered as highly pathogenic (Robertson 1979, MacMillan 1991, Urawa 1995). Studies by Urawa (1995) on I. necator in chum salmon Oncorhynchus keta showed that poor rearing conditions will significantly increase the pathogenicity of the parasite. Our irregular observations in winter, spring, summer and autumn at Danish farms suggest that this species is affected not only by temperature. Wootten \& Smith (1980) recorded an erratic occurrence of this parasite and chemical treatments and host resistance could influence the infection pattern.

Ciliates. The most pathogenic of the protozoans recorded was the ciliate Ichthyophthinius multifiliis, which elicited heavy mortalities in agreement with MacMillan (1991). The temperature-dependent infection (Bauer 1958, Wagner 1960) of this species was clearly demonstrated by its occurrence in relation to season and temperature. A corresponding pattern was also found in a salmon hatchery by Wootten \& Smith (1980). The decline in autumn could also partly be explained by the host response (Hines \& Spira 1974 , Dickerson \& Dawe 1995) which also in the present observations was expressed as pronounced hyperplasia of the fin epithelium and gill tissue. The use of malachite green for control has been prohibited since 1989 in Denmark and the current parasiticidal use of copper sulphate and formaldehyde against ichthyopthiriasis is less effective than the former. However, alternative efficacious drugs for succesful treatments are not readily available (Tojo et al. 1994, Dickerson \& Dawe 1995). Chilodonella piscicola was found only once and together with several other skin parasites. Although this genus is considered pathogenic (MacMillan 1991, Lom \& Dykova 1992), this was not evident in this study because of its rare occurrence. The suctorian Capriniana (Trichophrya) sp. does not appear to present a health hazard at the studied farms. This organism. was ranked as medium pathogenic to host fishes by MacMillan (1991) but is often regarded as an ectocommensal (Lom \& Dykova 1992).

The 3 species of Trichodina and Trichodinella epizootica expressed no clear seasonal variation or pathogenicity in the farms. Although these mobile peritrichs are ranked as of low pathogenicity (MacMillan 1991), mass occurrence will evidently affect the host by damaging epidermal cells (Lom \& Dykova 1992). The sessile peritrichs Epistylis sp., Ambiphrya sp. and Apiosoma $\mathrm{sp}$. attached to the skin and fins of trout throughout the year. Similar peritrichs are commonly found on farmed salmonids (Robertson 1979, Wootten \& Smith 1980, Poynton \& Bennett 1985, Rosengarten 1985) and are considered the least pathogenic of the ectoparasitic protozoans (MacMillan 1991).

\section{Metazoans}

Myxosporeans. The clustering of PKX cases from April to July and the low prevalences in the autumn and early winter are partly in accordance with earlier investigations. Previous studies by Olesen (1985) in one Danish trout farm (using conventional histology sections) indicated that infection occurred from May until late autumn. A possible immunity to the invading agent (Hedrick et al. 1993) resulting from previous infections might partly explain the results. Investigations by Hoffmann \& El-Matbouli (1994) showed that PKX cells could be found in non-clinically affected rainbow trout in late autumn, corresponding with these findings.

Monogeneans. Pathology. Both Gyrodactylis salaris and $G$. derjavini, as judged from the SEM studies, seem to produce some pathological effects on the trout epithelium resembling lesions elicited by $G$. salmonis and $G$. colemanensis in Canada (Cone \& Odense 1984, Cone \& Cusack 1988). However, the effects were not as pronounced as the devastating effect of $G$. salaris on the Norwegian salmon as shown by Malmberg (1993). $G$. derjavini has been reported to elicit morbidity and mortality in Salmo trutta (Ergens 1983), and rainbow trout should be considered vulnerable to this species. The genetically determined susceptibility of fishes to Gyrodactylus infections (Madhavi \& Anderson 1985. Bakke et al. 1991) could influence the distribution of the 2 congeners in the Danish farms. Even when the gyrodactylids elicit limited epithelial disruptions, the entry of associated bacteria through these infection routes could be of major importance (Cusack \& Cone 1986), a subject which should attract further interest.

Temperature. The 2 Gyrodactylus species both reproduced most energetically in the colder season when prevalence and abundance were highest. Thus they occurred predominantly at temperatures below $11^{\circ} \mathrm{C}$. 
The positive correlation between abundance and host size found in this study suggests that a larger body surface provides more substrate for parasite attachment as is known from other fish-monogenean systems (Buchmann 1989). However, it is noteworthy that fry and smaller fingerlings are often subjected to a more intensive prophylactic treatment with formaldehyde and chloramine than older fish. Such management practices will evidently affect these associations. In contrast to the regularly treated fry and fingerlings harbouring few parasites, spawners (normally not treated) carried infections on the fins and skin. This indicates the presence at the Danish farms of an infection reservoir in spawners as known from traditional monogenean-host systems (Bauer et al. 1973, Cone \& Cusack 1988, Buchmann et al. 1993).

Interactions between feral and cultured salmonids. The pathogenicity of the Norwegian strain of Gyrodactylis salaris to Norwegian (Johnsen \& Jensen 1988. Bakke et al. 1990, Malmberg 1993, Mo 1994) and Scottish (Bakke \& MacKenzie 1993) salmon stocks is notorious. As the spreading of parasites from rainbow trout farms to feral salmonids is considered possible (Mo 1991, Malmberg \& Malmberg 1993), attention should be given to the interactions between feral and farmed fish in spreading the parasite. Thus, the native Danish stocks of Salmo salar were eradicated years ago due to river regulation and pollution, and future restocking programmes should use salmon resistant to the parasite. Salmon stocks from the Baltic region, which probably is part of the original geographical distribution area of G. salaris (Malmberg \& Malmberg 1993), have an innate relative resistance to infection (Bakke et al. 1990, Malmberg \& Malmberg 1993).

Digeneans. The lens form of Diplostomum spathaceum may comprise more than one species (Chappell et al. 1994) and we cannot rule out the possibility that the forms detected at the Danish farms are not only D. spathaceum sensu stricto. However, using conventional morphological techniques only this species could be identified.

The parasite infection level raises some concern as the pathogenicity (Shariff et al. 1980, Brassard et al. 1982) and the growth reducing effect (Sato et al. 1976, Buchmann \& Uldal 1994j of eye fluke infections are well known.

The occurrence of Diplostomum spathaceum metacercaria in Farm 4 fish was caused by the presence of infected intermediate hosts in the farm. Thus $3.4 \%$ of Lymnaea pereger and $2.9 \%$ of $L$. stagnalis were releasing infective $D$. spathaceum cercariae in August 1994 (Buchmann et al. 1995b). As cercarial shedding and subsequent infection of rainbow trout is highly temperature dependent (Stables \& Chappel 1986a, b, Sous 1992, Lyholt \& Buchmann 1996), it is evident that the infection pressure is low in the colder season, when introduced fish will avoid infection, explaining the lower prevalences seen. Seasonal variation of eye fluke infection levels were previously described (Wootten 1974, Burrough 1978). The relatively moderate infection level in summer and autumn despite the presence of infected intermediate hosts could be explained by an immune reaction in the rainbow trout towards infective cercariae (Höglund \& Thuvander 1990). Prevention of infection through snail control at this farm is probably difficult as intermediate hosts and cercariae are able to enter the farm from the natural lake which supplies water to the facility. Whether filtration or increase of water flow (Field \& Irwin 1994) could solve these problems is yet to be investigated.

The presence of the few Tylodelphys clavata metacercaria in the vitreous humor is not considered to cause problems. As this parasite infection was not very prevalent and occurred in low abundances, no clear seasonal variation was evident. The source of infection was not identified. Natural infection intensities of $T$. clavata in feral fish (e.g. perch) are much higher (several hundreds per fish)(Kennedy 1981) and it is possible that infective cercariae shed in the water-supplying natural lake enter Farm 4 irregularly and in low numbers

Cestodes. No pathological disturbances were found due to cestode infections although these are known from salmonids infected with species of Proteocephalus (Engelhardt et al. 1988), Triaenophorus (Kuperman 1973, Bauer \& Solomatova 1984) and Eubothrium (Berland 1991, Bristow \& Berland 1991). The cestodes found at Farm 4 are evidently acquired by ingestion of copepods entering the farm with natural lake water. Thus, copepods are the first intermediate host for Eubothrium crassum (Vik 1963), Proteocephalus exiguus (syn. P. neglectus Hanzelova et al. 1995) (Hanzelova et al. 1990) and Triaenophorus nodulosus (Kuperman 1973). Wootten (1972) found a high infection rate of isolated rainbow trout receiving copepod-containing water from a connected reservoir stocked with infected trout. In contrast, in the present study the copepods entering the farm are probably relatively rarely infected with procercoids of these cestode species. The life cycle of Triaenophorus nodulosus includes pike as final host. As this predatory fish is absent from the trout farm, this also indicates that inflow of infected copepods from the lake (which is inhabited by pike) is responsible for the infection.

Crustaceans. The crustacean parasite Argulus foliaceus (Branchiura) was very rare, detected only once on a spawner, and is at present not a problematic parasite in the trout farms. However, as this species in some cases has shown pathogenicity to rainbow trout (Buchmann et al. 1995a, b), farmers should be aware of its possible occurrence and how to control it 
Previously recorded but now absent parasites. The absence of the previously prevalent Myxobolus cerebralis may be explained by the current use of well water and fibre-glass or concrete fish tanks for rearing of fry. In this way, intermediate hosts or actinospores in the parasite's life cycle (Wolf \& Markiw 1984, Markiw 1986) are prevented from reaching the fry.

Previously, marine fish offal was used as feed in the trout farms, which resulted in infections with anisakid third stage larvae (Christensen \& From 1978). However, since the early 1980 s Danish trout have been fed with commercial dry pelleted feed only. This explains the absence of anisakid marine nematodes from the trout farms.

\section{Conclusions}

As the present investigation has provided us with an overview of parasitic diseases in Danish trout farms we can now concentrate on control measures against the infections. The frequent use of chemicals may be reduced through development of immunoprophylactic measures and environmentally safe water treatment methods. Improved management practice (filtration of water) could even reduce the infection level of certain parasites. These issues will be subject to further investigations in the future.

Acknowledgements. This study was supported by the Danish Agricultural and Veterinary Research Council. The authors are indebted to Drs Vladimira Hanzelova (Slovak Republic) and Tomas Scholz (Czech Republic) for their identification of Proteocephalus cestodes.

\section{LITERATURE CITED}

Bakke TA, Jansen PA, Hansen LP (1990) Differences in the host resistance of Atlantic salmon, Salmo salar L., stocks to the monogenean Gyrodactylus salaris Malmberg, 1957. $J$ Fish Biol 37.577-587

Bakke TA, Janssen PA, Kennedy CR (1991) The host specificity of Gyrodactylus salaris Malmberg (Platyhelminthes. Monogenea): susceptibility of Oncorhynchus mykiss (Walbaum) under experimental conditions. J Fish Biol 39:45-57

Bakke TA, Mackenzie K (1993) Comparative susceptibility of native Scottish and Norwegian stocks of Atlantic Salmon, Salmo salar L., to Gyrodactylus salaris Malmberg: laboratory experiments. Fish Res 17:69-85

Bauer ON (1958) Biologie und Bekämpfung von Ichthyophthirius multifiljis Fouquet. Z Fisch Hilfswiss 7.575-581

Bauer ON, Musselius VA, Strelkov Yu A (1973) Diseases of pond fishes. Translated from Russian, Israel Program for Scientific Translations, Jerusalem

Bauer ON, Solomatova VP (1984) The cestode Trianophorus crassus (Pallas) (Pseudophyllidea: Triaenophoridae) as a pathogen of cage-reared salmonids. J Fish Dis 7:501-504

Berland B (1991) Cestoda, Bendelmark. (Cestodes, tapeworms). In: Poppe TT (ed) Fiskehelse (Fish health). John Grieg Forlag, Oslo, p 246-250
Brassard P, Rau ME, Curtis MA (1982) Infection dynamics of Diplostomum spathaceum cercariae and parasite-induced mortality of fish host. Parasitology 85:489-493

Bristow G, Berland B (1991) The effect of long term, low level Eubothrium sp. (Cestoda: Pseudophyllidea) infection on growth in farmed salmon (Salmo salar L.). Aquaculture 98: $325-330$

Buchmann K (1989) Relationship between host size of Anguilla anguilla and the infection level of the monogeneans Pseudodactylogyrus spp. J Fish Biol 35:599-601

Buchmann K. Slotved HC, Darnas D (1993) Epidemiology of gill parasite infections in Cyprinus carpio in Indonesia and possible control methods. Aquaculture 118:9-21

Buchmann K, Uldal A (1994) Effects of eyefluke infections on growth of rainbow trout (Oncorhynchus mykiss) in a mariculture system. Bull Eur Ass Fish Pathol 14:104-1.07

Buchmann K, Uldal A (1996) Temperature and $\mathrm{pH}$ dependent in vitro cultivation of Hexamita salmonis. Dis Aquat Org $24: 169-172$

Buchmann K, Uldal A, Lyholt H (1995a) A checklist of metazoan parasites from rainbow trout (Oncorhynchus mykiss) Acta Vet Scand 36:299-318

Buchmann K, Uldal A, Lyholt H (1995b) Parasite infections in Danish trout farms. Acta Vet Scand 36:283-298

Bucke D, Feist SW, Clifton-Hadley RS (1991) The occurrence of proliferative kidney disease (PKD) in cultured and wild fish: further investigations. J Fish Dis 14:583-588

Burrough RJ (1978) The population biology of two species of eyefluke, Diplostomum spathaceum and Tylodelphys clavata, in roach and rudd. J Fish Biol 13:19-32

Chappell LH, Hardie LJ, Secombes CJ (1994) Diplostomiasis: the disease and host-parasite interactions. In: Pike AW, Lewis JW (eds) Parasitic diseases of fish. Samara Publishing, Tresaith, p 59-86

Christensen NO, Jensen M, Rasmussen CI (1963) Fish diseases in Denmark. Bull Off Int Epiz 59:21-29

Christensen S, From J (1978) Rundorme og deres bekæmpelse hos dambrugsfisk. (Roundworms and their eradication in farmed fish). Ferskvandsfiskeribladet 8:94-100 (in Danish)

Cone DK, Cusack R (1988) A study of Gyrodactylus colemanensis Mizelle and Kritsky, 1967 and Gyrodactylus salmonis (Yin and Sproston, 1948) parasitizing captive salmonids in Nova Scotia. Can J Zool 66:409-415

Cone DK, Odense PH (1984) Pathology of five species of Gyrodactylus Nordmann, 1832 (Monogenea). Can J Zool 62:1084-1088

Cusack $R$, Cone DK (1986) A review of parasites as vectors of viral and bacterial diseases of fish. J Fish Dis 9: $169-171$

Davis HS (1926) Octomitus salmonis, a parasitic flagellate of trout. Bull Bureau of Fish, Washington 42:9-26

Dickerson HW, Dawe DL (1995) Ichthyophthirius multifilis and Cryptocaryon irritans (Phylum. Ciliophora). In: Woo PTK (ed) Fish diseases and disorders, Vol. 1 CAB International, Wallingford

Engelhardt A, Mirle C, Granitza I, Petermann H (1988) Untersuchungen zum Vorkommen, zur Schadenwirkung und Bekämpfung von Proteocephalus neglectus bei Regenbogenforellen in der Netzkäfighaltung. Monh Vet med 43: $169-172$

Ergens R (1983) Gyrodactylus from Eurasian freshwater salmondae and thymallidae. Folıa Parasitol 30:15-26

Ferguson HW (1979) Scanning and transmisston electron microscopical observations on Hexamita salmons (Moore, 1922) related to mortalities in rainbow trout fry Salmo gardneri Richardson. J Fish Dis 2:57-67 
Field JS, Irwin SWB (1994) The epidemiology, treatment and control of diplostomiasis on a fish farm in Northern Ireland. In: Pike AW, Lewis JW (eds) Parasitic diseases of fish. Samara Publishing, Tresaith, p 87-100

From J, Horlyck V (1981) First recorded occurrence of Proteocephalus percae (Müller, 1780) in Danish farmed trout. Bull Eur Ass Fish Pathol 1:40-41

Hanzelova V. Scholz, T (1992) Redescription of Proteocephalus neglectus La Rue, 1911 (Cestoda: Proteocephalidae), a trout parasite, including designation of its lectotype. Folia Parasitol 39:317-323

Hanzelova V. Scholz T, Fagerholm HP (1995) The synonymy of Proteocephalus neglectus La Rue, 1911 with P. exiguus La Rue, 1911, two fish cestodes from the Holarctic Region. Syst Parasitol 30:173-185

Hanzelova V, Zitnan R, Sysoev AV (1990) The seasonal dynamics of invasion cycle of Proteocephalus neglectus (Cestoda). Helminthologia 27:135-144

Hare GM, Frantsi C (1974) Abundance and potential pathology of parasites infecting salmonids in Canadian maritime hatcheries. J Fish Res Bd Can 31:1031-1036

Hedrick RP, MacConnell E, de Kinkelin P (1993) Proliferative kidney disease of salmonid fish. Annu Rev Fish Dis 3: $277-290$

Hedrick RP, Marin M, Castagnaro M, Monge D, de Kinkelin P (1992) Rapid lectin based staining procedure for the detection of the myxosporean causing proliferative kidney disease in salmonid fish. Dis Aquat Org 13: $129-132$

Hines RS, Spira DT (1974) Ichthyophthiriasis in the mirror carp Cyprinus carpio (L.) V. J Fish Biol 6:373-378

Hoffmann RW. El-Matbouli M (1994) Proliferative Kidney Disease (PKD) as an important myxosporean infection in salmonid fish. In: Pike AW, Lewis JW (eds) Parasitic diseases of fish. Samara Publishing, Tresaith, p 3-16

Höglund J, Thuvander A (1990) Indications of non-specific protective mechanisms in rainbow trout Oncorhynchus mykiss with diplostomosis. Dis Aquat Org 8:91-97

Horlyck V (1980) En ny parasit i danske dambrugs-ørreder (A new parasite from Danish farmed trout). Ferskvandsfiskeribladet 4:68-69 (in Danish)

Johnsen BO, Jensen AJ (1988) Introduction and establishment of Gyrodactylus salaris Malmberg, 1957, on Atlantic salmon, Salmo salar L., fry and parr in the River Vefsna, northern Norway. J Fish Dis 11:35-45

Kennedy CR (1981) Long term studies on the population biology of two species of eyefluke, Diplostomum gasterostei and Tylodelphys clavata (Digenea: Diplostomatidae), concurrently infecting the eyes of perch, Perca fluviatilis. J Fish Biol 19:221-236

Kennedy CR, Bush AO (1994) The relationship between pattern and scale in parasite communities: a stranger in a strange land. Parasitology 109:187-196

Kuperman Bl (1973) Tapeworms of the genus Triaenophorus, parasites of fishes. Nauka Publishers, Leningrad. Translated from Russian (US Department of the Interior and National Science Foundation, Washington, DC, by Amerind Publishing Co., New Delhi, 1981)

Lom J, Dykova I (1992) Protozoan parasites of fishes. Developments in aquaculture and fisheries science, 26. Elsevier, Amsterdam, p 1-315

Lyholt HCK, Buchmann K (1996) Diplostomum spathaceum: effects of temperature and light on cercarial shedding and infection of rainbow trout. Dis Aquat Org 25:169-173

MacMillan JR (1991) Biological factors impinging upon control of external protozoan fish parasites. Annu Rev Fish Dis $119-131$
Madhavi R, Anderson RM (1985) Variability in the susceptibility of the fish host Poecllia reficulata to infection with Gyrodactylus bullatarudis. Parasitology 91:531-544

Malmberg G (1957) Om forekomsten af Gyrodactylus på svenske fisk (On the occurrence of Gyrodactylus on Swedish fishes). Skr sodr Sver Fisk For Arsskr 1957, 1956. $19-76$

Malmberg G (1973) Gyrodactylus infestations on species of Salmo in Danish and Swedish hatcheries. Norw J Zool 21: $325-326$

Malmberg G (1993) Gyrodactylidae and gyrodactylosis of salmonidae. Bull Fr Peche Piscic 328:5-46

Malmberg G. Malmberg M (1993) Species of Gyrodactylus (Platyhelminthes, Monogenea) on salmonids in Sweden. Fish Res 17:59-68

Margolis L, Esch GW, Holmes JC, Kuris AM, Schad GA. (1982) The use of ecological terms in parasitology (report of an ad hoc committee of the American Society of Parasitologists). J Parasitol 68:131-133

Markiw ME (1986) Salmonid whirling disease: dynamics of experimental production of the infective stage-the Triactinomyxon spore. Can J Fish Aquat Sci 43:521-526

McGuigan JB, Sommerville C (1985) Studies on the effects of cage culture of fish on the parasite fauna in a lowland freshwater loch in the west of Scotland. Z Parasitenkde $71: 673-682$

Mo TA (1991) Variations of opisthaptoral hard parts of Gyrodactylus salaris Malmberg, 1957 (Monogenea: Gyrodactylidae) on rainbow trout Oncorhynchus mykiss (Walbaum, 1792) in a fish farm, with comments on the spreading of the parasite in south-eastern Norway. Syst Parasitol 20:1-9

Mo TA (1994) Status of Gyrodactylus salaris problems and research in Norway. In: P1ke AW, Lewis JW (eds) Parasitic diseases of fish. Samara Publishing, Tresaith, p 43-56

Moore E (1923) Octomitus salmonls, a new species of intestinal parasite in trout. Trans Am Fish Soc 54:74-93

Olesen NJ (1985) PKD i 1984 (PKD in 1984). Ferskvandsfiskeribladet 5:126-129 (in Danish)

Poynton SL (1986) Distribution of the flagellate Hexamita salmonis Moore, 1922 and the microsporidian Loma salmonae Putz, Hoffman and Dunbar, 1965 in brown trout, Salmo trutta L., and rainbow trout, Salmo gairdneri Richardson, in the River Itchen (U.K.) and three of its fish farms. J Fish Biol 29:417-429

Poynton SL, Bennett CE (1985) Parasitic infections and their interactions in wild and cultured brown trout and rainbow trout from the river ltchen, Hampshire. In: Ellis AE (ed) Fish and shellfish pathology. Academic Press, London, p 353-357

Robertson DA (1979) Host parasite interactions between Ichthyobodo necator (Henneguy, 1883) and farmed salmonids. J Fish Dis 2:481-491

Rosengarten R (1985) Parasitologische Untersuchungen an Regenbogenforellen (Salmo gairdneri Richardson) in einer Forellenteichwirtschaft in Niedersachsen. Dissertation. Fachgebiet Fischkrankheiten und Fischhaltung der Tierärztlichen Hochschule Hannover

Sato T, Hoshina T, Horiuchi M (1976) On worm cataract of rainbow trout in Japan. Bull Jap Soc Sci Fish $42: 249$

Shariff M, Richards RH, Sommerville C (1980) The histopathology of acute and chronic infections of rainbow trout, Salmo gairdneri Richardson with eye flukes, Diplostomum spp. J Fish Dis 3:455-465

Smothers JF, von Dohlen CD, Smith LH, Spall RD (1994) Molecular evidence that the myxozoan protists are metazoans. Science 265:1719-1721 
Sous SM (1992) Influence of abiotic factors on emission and survival of cercariae of Diplostomum chromatophorus (Brown, 1931) (Trematoda, Diplostomidae). Ecol Parasitol 1:154-159

Stables JN, Chappell LH (1986a) Diplostomum spathaceum (Rud. 1819): effects of physical factors on the infection of rainbow trout (Salmo gairdneri) by cercariae. Parasitology 93:71-79

Stables JN, Chappell LH (1986b) The epidemiology of diplostomosis in farmed rainbow trout from north-east Scotland. Parasitology 92:699-710

Tojo JL, Santamarina MT, Ubeira FM, Leiro J, Sanmartin ML (1994) Trials for the control of ichthyophthiriosis in rainbow trout (Oncorhynchus mykiss). Bull Eur Ass Fish Pathol 14:148-152

Uldal A, Buchmann K (1996) Parasite host relations: Hexamita salmonis in rainbow trout Oncorhynchus mykiss. Dis Aquat Org 25:233-238

Urawa S (1995) Effects of rearing conditions on growth and mortality of juvenile chum salmon (Oncorhynchus keta) infected with Ichthyobodo necator. Can J Fish Aquat Sci $52: 18-23$

Uzmann JR, Paulik GJ, Hayduk SH (1965) Experimental hexamitiasis in juvenile coho salmon (Oncorhynchus kisutch) and steelhead trout (Salmo gairdneri). Trans Am Fish Soc 94:53-61

Responsible Subject Editor: W. Körting, Hannover, Germany
Vik R (1963) Studjes of the helminth fauna of Norway. IV Occurrence and distribution of Eubothrium crassum (Bloch, 1779) and E. salvelini (Schrank, 1790) (Cestoda) in Norway, with notes on their life cycles. Nytt Mag Zool 11 $47-73$

Wagner G (1960) Der Entwicklungszyklus von Ichthyophthirius multifiliis Fouquet und der Einfluß physikalischer und chemischer Außenfaktoren. Z Fisch 9:425-443

Wolf K, Markiw E (1984) Biology contravenes taxonomy in the Myxozod: new discoveries show alternation of invertebrate and vertebrate hosts. Science 225:1449-1452

Wootten R (1972) Occurrence of Eubothrium crassum (Bloch, 1779) (Cestoda: Pseudophyllidea) in brown trout, Salmo trutta L., and rainbow trout, S. gairdneri Richardson, 1836, from Hanningfield Reservoir, Essex. J Helminthol 46: $327-339$

Wootten R (1974) Observations on strigeid metacercariae in the eyes of fish from Hanningfield reservoir, Essex, England. J Helminthol 48:73-83

Wootten R, Smith JW (1980) Studies on the parasite fauna of juvenile Atlantic salmon, Salmo salar L., cultured in fresh water in eastern Scotland. Z Parasitenkde 63:221-231

Zitnan R, Cankovic M (1970) Comparison of the epizootological importance of the parasites of Salmo gairdneri irideus in the two coast areas of Bosnia and Herzegovina. Helminthologia 11:161-166

Manuscript first received: June 10,1996

Revised version accepted: September 11, 1996 